\title{
EVALUATION OF THE IMPROVEMENT POSSIBILITIES OF PHYSICAL PROPERTIES OF MINERAL FODDER ADDITIVES
}

\author{
Paweł Sobczak ${ }^{*}$, Kazimierz Zawiślak, Jacek Mazur, Marian Panasiewicz \\ Department of Engineering and Food Machines, University of Natural Sciences in Lublin \\ "Corresponding author: e-mail: pawel.sobczak@up.lublin.pl
}

\begin{tabular}{|c|c|}
\hline ARTICLE INFO & ABSTRACT \\
\hline $\begin{array}{l}\text { Article history: } \\
\text { Received: March } 2017 \\
\text { Received in the revised form: } \\
\text { April } 2017 \\
\text { Accepted: May } 2017\end{array}$ & \multirow{2}{*}{$\begin{array}{l}\text { The paper presents a change in physical properties of loose, dust } \\
\text { fodder additives (aluminosilicate) after mixing them with oil or glyc- } \\
\text { erine. Additives where mixed in a blade mixer with the same mixing } \\
\text { time for all samples, which was } 1 \text { minute. Tests with oil or glycerine } \\
\text { were carried out in the following amounts: } 5 \%, 10 \% \text {. For mixtures of } \\
\text { additives with oil or glycerine a selected group of physical properties } \\
\text { was determined. Method of determination of physical properties was } \\
\text { the same for all samples i.e. the same additives - without oil and } \\
\text { glycerine as well as mixtures with their participation. Obtained re- } \\
\text { search results and their analysis unanimously indicate that adding any } \\
\text { amount of oil or glycerine for additives improves selected physical } \\
\text { properties of mixtures. }\end{array}$} \\
\hline $\begin{array}{l}\text { Key words: } \\
\text { mixing, } \\
\text { physical properties, } \\
\text { fodder additives, } \\
\text { fodder }\end{array}$ & \\
\hline
\end{tabular}

\section{Introduction}

Mixing is an essential stage in the industrial production of fodder mixtures. Blade mixers or band mixers for which producer states theoretical time of indispensable mixing of raw materials are the most often used. However, the mixing time depends on physical properties of mixed raw material and the time given by a producer of a mixer should be corrected after the tests on mixing uniformity (Laurent et al., 2002). Homogeneity of a mixture is checked, inter alia, with microindexes namely with iron filings (Zawiślak et al., 2012, Królczyk et al., 2005, 2008). Standard ADAE (no.S303) describes the procedure of operation (Siiriä and Yliruusi, 2009, Zawiślak et al., 2011).

Fodder additive means various substances used in feeding animals as supplementation of basic nutrients, vitamins and mineral compounds. Fodder additives favourably influence generally understood health of animals and improve functioning of their organisms leading to faster and efficient increase of muscle and fat tissue. Their presence in the feed dose increases productivity, improves the fodder quality (image, taste, smell, consistency, shell life) (Grochowicz and Walczyński, 2004, Heidenreich and Strauch, 2000, Putier 2001).

The following are the most often used fodder additives:

- probiotics,

- fodder enzymes,

- aromatic and taste additives,

- dyes, 
- preservatives,

- detoxification - substances including an active group (e.g. aluminosilicate) which are not digested but bind toxic metabolites and mitotoxines secreted by undesired microorganisms which, as a result, go through a digestive tract in the unchanged form and are egested with feces without any detrimental influence on the animal body

- antioxidants,

- other different food products (Matuszek 2012, Zawiślak et al., 2011; Molognoni et al., 2017).

\section{The objective and scope of research}

The objective of the presented research is to improve physical properties of fodder additives with regard to the possibilities of a precise dosing to fodder mixtures and reduce their powder character.

\section{Methodology of research}

Two different aluminosilicates marked as follows were used in the tests: "Additive 1" and "Additive 2" as labels used in all stages of experiment. Aluminosilicates included inter alia: $\mathrm{SiO}_{2}, \mathrm{Al}_{2} \mathrm{O}_{3}, \mathrm{Fe}_{2} \mathrm{O}_{3}, \mathrm{FeO}, \mathrm{TiO}_{2}, \mathrm{MnO}, \mathrm{MgO}, \mathrm{CaO}, \mathrm{Na}_{2} \mathrm{O}, \mathrm{K}_{2} \mathrm{O}, \mathrm{Li}_{2} \mathrm{O}, \mathrm{P}_{2} \mathrm{O}_{5}$, they differed with various content of particular compounds between each other. Basic physical properties were determined according to the binding standard and then oil or glycerine were introduced in the following amounts: 5\%, 10\%. Aluminosilicates were greased in a blade mixer F-6 RVC type by Forberg. A blade mixer was used for this purpose and liquid was dosed by a sprinkling nozzle (Fig. 1). A previously prepared sample was weighted and poured into the mixer. Then, amount of oil or glycerine which was 5 was weighted and then $10 \%$ of the mass raw material were prepared and poured to a cylinder, where with the use of a pump it was pumped into the mixer. The mixing time for all samples was $1 \mathrm{~min}$. The mixer was filled in $70 \%$ and the batch was 3 kilo for each sample.

After the process of greasing physical properties of the mixture were determined in the same way as in samples without oil or glycerine.

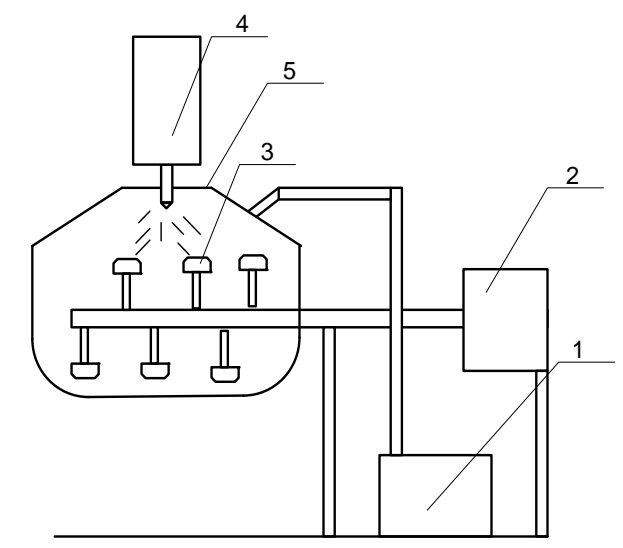

Figure 1. Greasing stand scheme: 1 - vacuum pump, 2 - mixture engine, 3 - mixing blades, 4 - spray tank, 5 - case 


\section{Results and discussion}

Obtained research results and their analysis unanimously indicate that adding any amount of oil or glycerine to additives improves some physical properties of mixtures. Changes of selected physical properties of additives, after oil or glycerine was introduced, were presented below. Figure 2 present changes of the angle of chute in relation to the amount and type of the introduced liquid. The highest increase since as much as $32 \%$ for additive 1 occurred after oil in the amount of $10 \%$ was introduced. A high increase of the angle of chute confirms clumping and lumpiness of the structure of mixture which in practice is not good for dosing. After glycerine was introduced, the angle of chute for additive 1 increased within 1-3 units and did not cause considerable changes in the product loose character. Additive 2 had different relations of the angle of chute. Introduction of oil or glycerine to this additive caused decrease of the angle of chute value within 1-4 units.

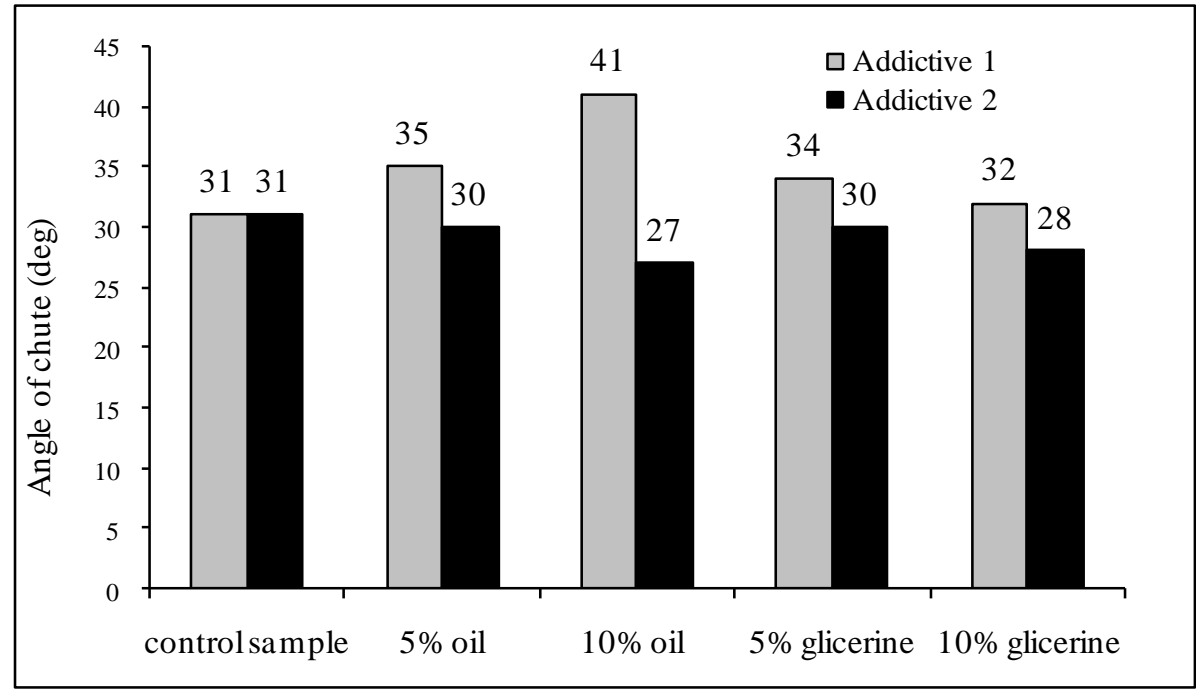

Figure 2. Changes of angle of chute in relation to introduced oil or glycerine

Introduction of oil and glycerine in the amount of 5 or $10 \%$ led to the decrease of angle of repose from 1 to 3 measuring units (Figure 3). Only, introduction of oil in the amount of $10 \%$ for additive 1 caused the increase of the angle of repose by 2 measuring units.

As a result of introduction of oil or glycerine to additives the bulk density and tap density increase. The obtained mixture has a high bulk density which is even approx. 940 kilo m ${ }^{3}$ after oil in the amount of $10 \%$ was introduced to additive 2 (Figure 4-5). 
P. Sobczak, K. Zawiślak, J. Mazur, M. Panasiewicz

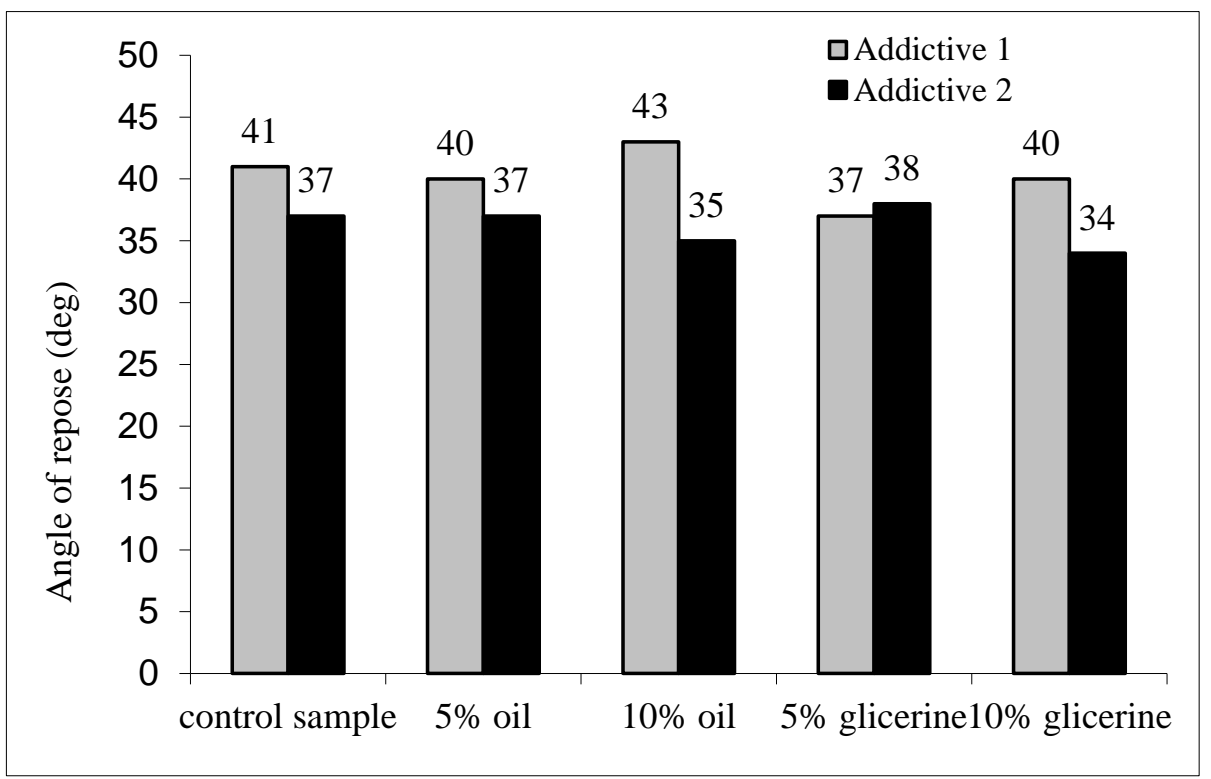

Figure 3. Changes of angle of repose in relation to introduced oil or glycerine

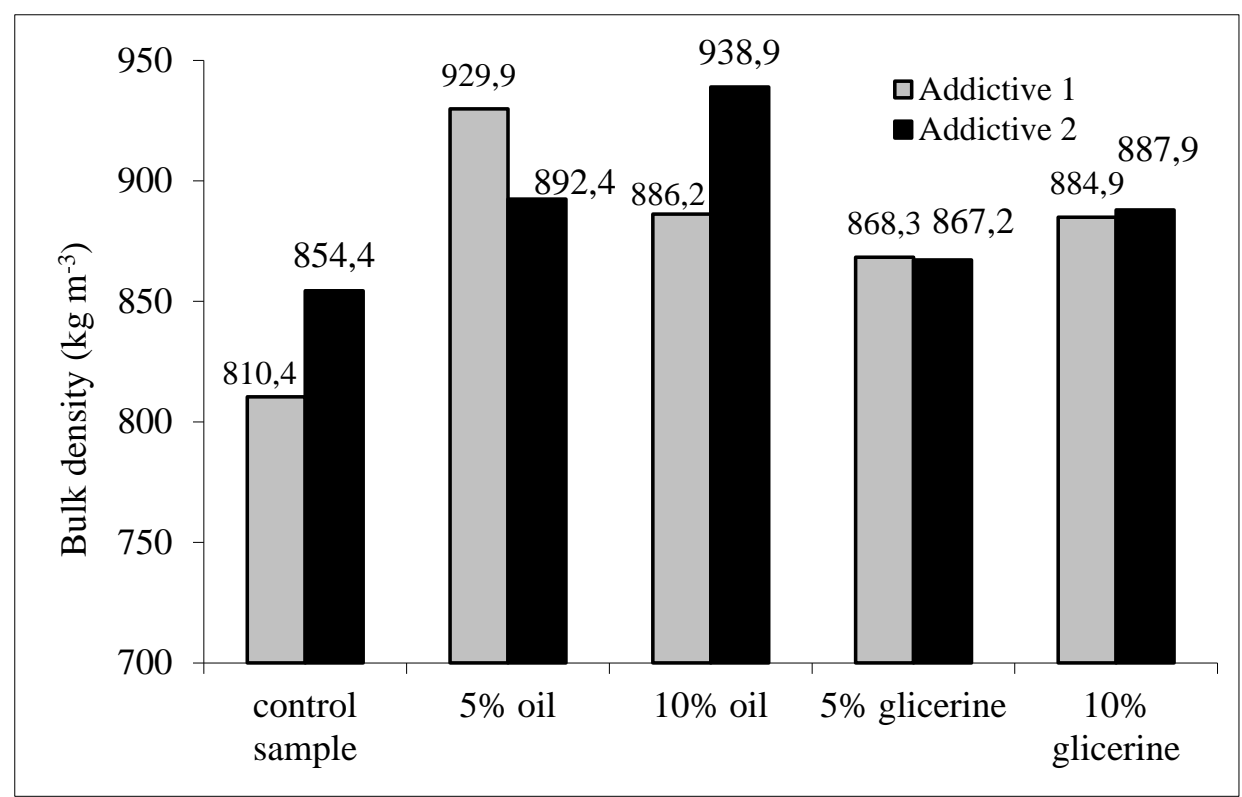

Figure 4. Changes of bulk density in relation to introduced oil or glycerine 
Evaluation of the improvement...

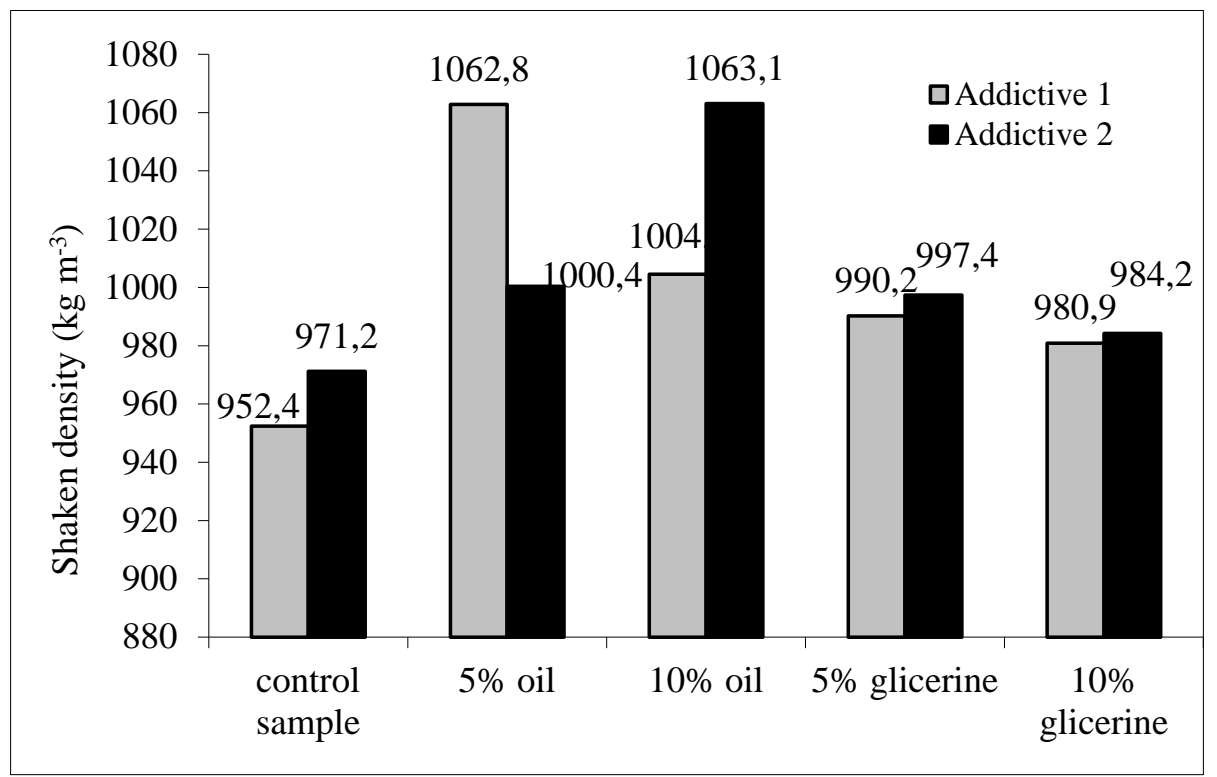

Figure 5. Changes of shaken density in relation to introduced oil or glycerine

After oil or glycerine was introduced to additive 1 the bulk density and shaken density of the mixture decrease in comparison to $10 \%$ of introduction. For additive 1 it results from the tendency to form agglomerates with a bigger diameter in comparison to agglomerates with participation of $5 \%$ of oil or glycerine.

Figure 6 presents size distribution of additive 1 after oil or glycerine was introduced. Additive 1 had a great amount of powder fraction which is $70 \%$. Introduction of oil in the amount of $5 \%$ reduced its participation by approximately $8 \%$ and introduction of $10 \%$ oil reduced powder fraction by approx. 23\%. Increase of fraction within $0.1-0.2 \mathrm{~mm}$ takes place. In comparison to the control sample, the amount of the finest fraction i.e. below 0.1 $\mathrm{mm}$ reduced. Introduction of glycerine has similar effects and reduction of the finest fraction is respectively approx. $33 \%$ and approx. $39 \%$. Obtaining fraction above $0.1 . \mathrm{mm}$ has a utilitarian meaning for industrial production of fodders with regard to unfavourable impact of powder fraction for the granulation process, inter alia, blocking and sticking in rollers and matrix of a granulator takes place.

Figure 7 presents size distribution of additive 2. This additive had a considerably lower participation of powder fraction in comparison to additive 1 . This proves a smaller inclination to staying and higher looseness of raw material.

Introduction of oil or glycerine to additive 2 caused reduction of powder fraction by approximately $17 \%$ for oil and glycerine; however, low participation of powder fraction in a control sample (11.8\%) proves high looseness of the product without the necessity of introducing oil or glycerine. 
Addictive 1

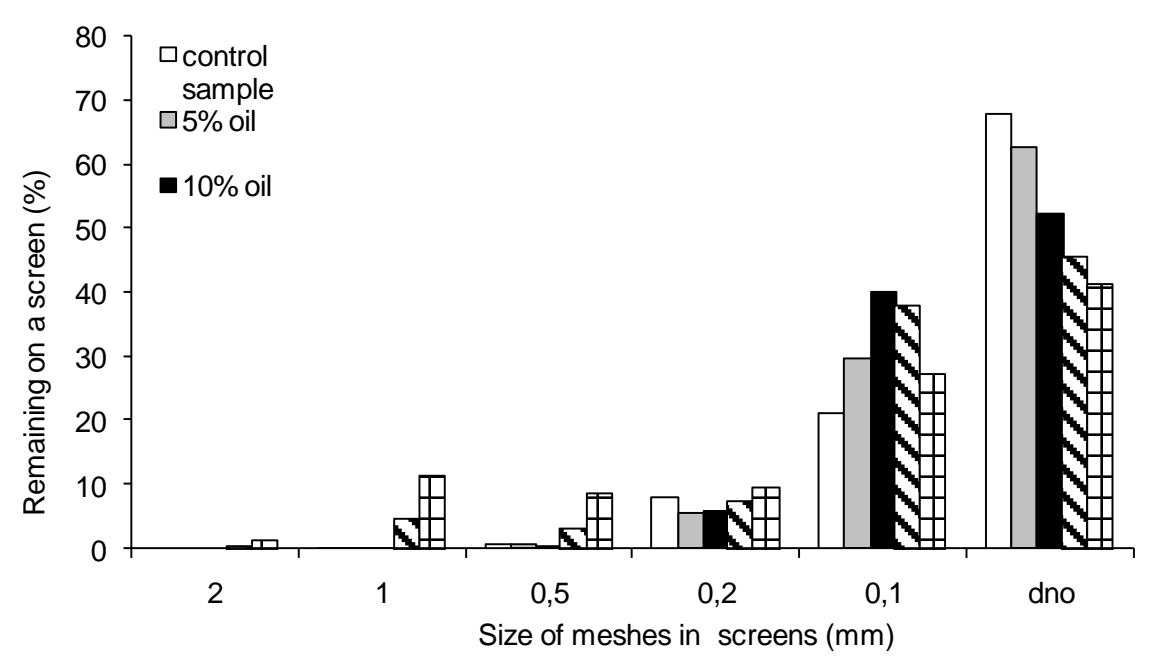

Figure 6. Size distribution of additive 1 in relation to the introduced oil or glycerine

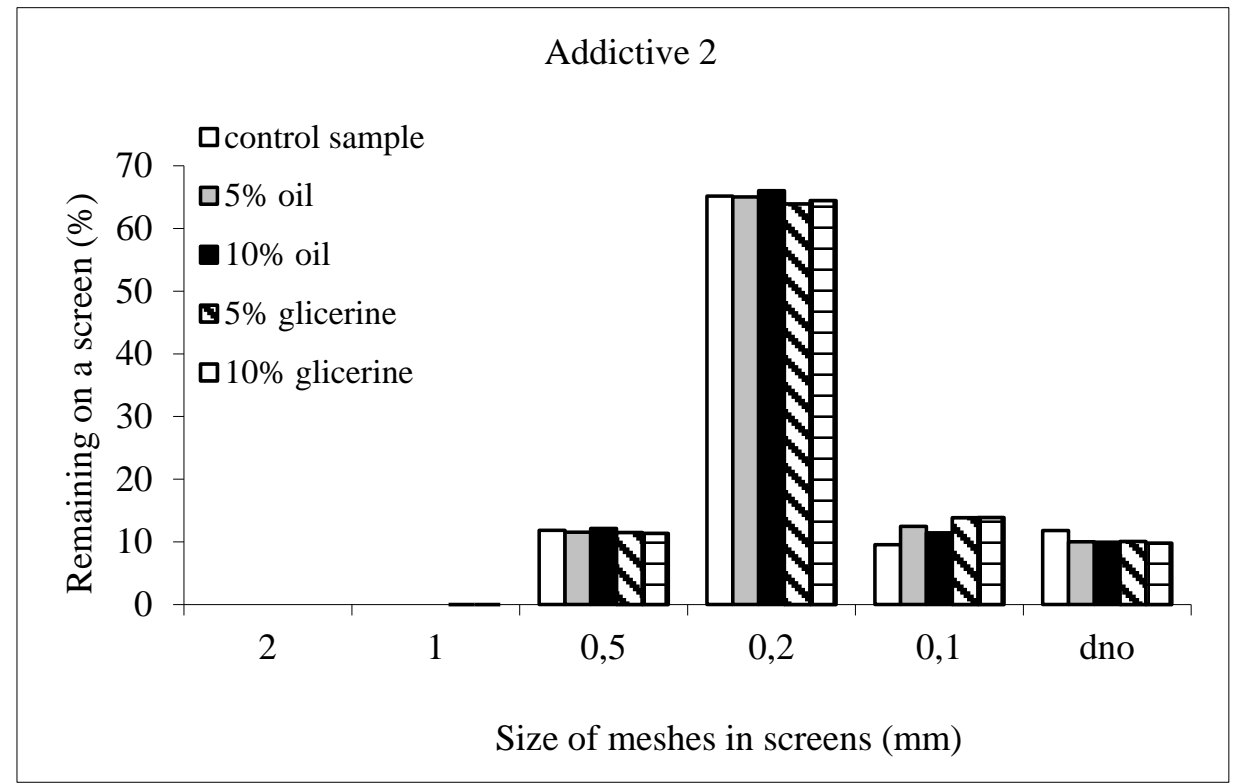

Figure 7. Size distribution of additive 2 in relation to the introduced oil or glycerine

The current research evaluated the impact of fat content in fodder mixtures on the granulation process and kinetic resistance of granulate (Kulig and Laskowski, 2005). Because of 
Evaluation of the improvement...

the decrease of kinetic resistance of granulate after fat was added to the fodder mixture, research was carried out on possibility of spraying hot fat on the formed granulate (Zawiślak, 1997). Attempts were made to generate a grain and fat concentrate for usage as an additive in fodder mixtures which raised kinetic resistance of granulate (Sobczak, 2013). There are no studies concerning combination of fat with mineral additives and its introduction in this form. The presented research constitute practical combination of the introduced additives with fat in order to improve inter alia, looseness of addtives and increase of the fat participation in fodder mixture.

\section{Conclusions}

Based on the research which was carried out, the following conclusions have been made:

- Oil or glycerine addition influences the change of physical properties of additive 1. Introduction of oil in the amount of $10 \%$ influences the increase of the angle of repose and chute angle which results in the reduced looseness of the product.

- Introduction of oil in the amount of $5 \%$ to additive 1 seems to be optimal, which favourably influence the size distribution and physical properties of the product do not change significantly.

- Introduction of oil or glycerine to additive 2 does not influence the size distribution and improvement of looseness. Enriching the fodder mixture with fat is the only advantage.

- The obtained results of research tend to improve the physical properties of fodder additives "Additive 1" and "Additive 2" through introduction to their structure of complex percentage oil and glycerine participations, will allow development of an efficient and precise method of their microdosing in the feed dosing line for pigs.

Research was funded by means of the scientific project BIOSTRATEG2/298357/ 8/NCBR/2016. Developing innovative technologies of complex utilization of waste generated during fattening of pigs - KompUtyl co-financed by the National Centre of Research and Development as a part of Strategic plan of scientific research and development work 'Natural environment, agriculture and forestry' BIOSTRATEG

\section{References}

Grochowicz, J., Walczyński, S. (2004). The effect of some technological factors on the consumption of energy at mixing granular materials. TEKA Komisji Motoryzacji i Energetyki Rolnictwa, 4, 71-76.

Heidenreich, E., Strauch, W. (2000). Decisive factors for solids mixing process in compound feed production. Part 2. Feed Magazine, 7-8, 286-292.

Królczyk, J., Matuszek, D., Tukiendorf, M. (2005). Analiza stanów składu niejednorodnej mieszaniny ziarnistej w procesie przygotowania paszy dla gołębi w warunkach przemysłowych z wykorzystaniem metody taksonomicznej. Inżynieria Rolnicza, 14(74), 193-201.

Królczyk, J., Matuszek, D., Tukiendorf, M. (2008). Badanie przebiegu procesu mieszania dwuskładnikowego układu ziarnistego metodą wysypu kominowego. Inżynieria Rolnicza, 11(109), 157-163. 
Kulig, R., Laskowski, J. (2005). Wpływ zawartości thuszczu na process granulowania materiałów paszowych. Inżynieria Rolnicza, 7, 59-68.

Laurent, B.F.C., Bridgwater, J., Parker, D.J. (2002). Convection and segregation in a horizontal mixer. Powder Technology, 123, 9-18.

Matuszek, D. (2012). Analiza procesu mieszania pasz dla drobiu w przemysłowej wytwórni pasz. Inżynieria Rolnicza, 2(136), 2013-220.

Molognoni, L. Ploencio, L.A.D., Machado, A.M.L., Daguer, H. (2017). The role of measurement uncertainty in the conformity assessment of the chemical composition of feeds. Microchemical Journal, 131, 79-91.

PN-65/Z-04005 - Oznaczanie kąta zsypu

PN-73R-74007 - Oznaczanie kąta usypu.

PN-89 R-64798 Pasze - oznaczanie rozdrobnienia.

PN-EN ISO 8460:1999. Oznaczanie gęstości nasypowej swobodnej i gęstości nasypowej ubitej.

Putier F. 2001. Assessment of homogenity of compound feed. Feed Magazine, 3, 98-108.

Siiriä, S., Yliruus, J. (2009). Determining a value for mixing: Mixing degree. Powder Technology, 196, 309-317.

Sobczak, P. (2013). Zastosowanie obróbki ciśnieniowo-termicznej w wytwarzaniu zbożowotluszczowych koncentratów paszowych. Acta Agrophysica. Monographiae. ISBN 2084-3429.

Zawiślak, K. 1997. Metody natłuszczania pasz. Pasze Przemystowe, 5, 20-22.

Zawiślak, K., Grochowicz, J., Sobczak, P. (2011). The analysis of mixing degree of granular products with use of microtracers. TEKA Komisji Motoryzacji I Energetyki Rolnictwa. V. XIC, 335-342.

Zawiślak, K., Sobczak, P., Wełdycz, A. (2012). Mixing as CCP in the production of industrial feed. Journal of Central European Agriculture, 13(3), 554-562.

\section{OCENA MOŻLIWOŚCI POPRAWY WLAŚCIWOŚCI FIZYCZNYCH MINERALNYCH DODATKÓW PASZOWYCH}

Streszczenie. Prezentowana praca przedstawia zmianę właściwości fizycznych sypkich, pylistych dodatków paszowych (glinokrzemianów) po wymieszaniu ich z olejem lub gliceryną. Mieszanie dodatków przeprowadzono w mieszarce łopatkowej z jednakowym czasem mieszania dla wszystkich prób wynoszącym $1 \mathrm{~min}$. Wykonano próby z udziałem oleju lub gliceryny w następujących ilościach: $5 \%, 10 \%$. Dla otrzymanych w ten sposób mieszanin dodatków z udziałem oleju lub gliceryny określono wybraną grupę właściwości fizycznych. Sposób określania cech fizycznych był taki sam dla wszystkich próbek tj. samych dodatków - bez udziału oleju i gliceryny, jak i mieszanin - z ich udziałem. Uzyskane wyniki badań i ich analiza jednoznacznie wskazują, iż dodanie określonej ilości oleju lub gliceryny do dodatków wpływa na poprawę wybranych właściwości fizycznych mieszanin.

Słowa kluczowe: mieszanie, właściwości fizyczne, dodatki paszowe, pasze 